\title{
SEROPREVALENCE OF IgG ANTIBODIES AGAINST BORRELIA BURGDORFERI IN DOGS IN BELGRADE AREA, SERBIA
}

\author{
OBRENOVIĆ Sonja ${ }^{1 *}$, RISTANOVIĆ Elizabeta ${ }^{2}$, ČEKANAC Radovan ${ }^{3}$, \\ RADULOVIĆ Željko ${ }^{4}$, ILIĆ Vesna ${ }^{4}$
}

${ }^{1}$ Department of Infectious Diseases of Animals and Bees, Faculty of Veterinary Medicine, University of Belgrade, Bulevar Oslobodjanja 18, 11000 Belgrade, Serbia; ${ }^{2}$ Institute of Microbiology, Military Medical Academy, Crvotravska 17, 11000 Belgrade, Serbia; ${ }^{3}$ Institute of Epidemiology, Military Medical Academy, Crnotravska 17, 11000 Belgrade, Serbia; ${ }^{4}$ Instutute for Medical Research, University of Belgrade, Dr Subotića 4, 11129 Belgrade 102, Serbia.

(Received $14^{\text {th }}$ July 2014; Accepted $20^{\text {th }}$ January 2015)

\begin{abstract}
In this study the seroprevalence of anti-Borrelia burgdorferi $\mathrm{IgG}$ antibodies in populations of naturally exposed dogs in the Belgrade area was determined. Serum samples of 215 dogs were tested with in-house made indirect immunofluorescent-antibody assay (IFA), enzyme-linked immunosorbent assay (ELISA), and Western blot assay (WB). Sera were from 34 pet dogs suspected of having Lyme borreliosis, 41 hunting dogs, 125 shelter dogs, and 15 clinically healthy pet dogs. Results of WB were used as a standard against which the performances of ELISA and IFA were evaluated. ELISA was significantly more sensitive than IFA ( 84.8 v $67.9 \%$ ), whereas the specificities of these tests were just slightly different $(94.4 \%$ vs $92.6 \%)$. Borrelia burgdorferi seroprevalence of $24.7 \%$ among tested dogs was recorded by WB test. The highest seroprevalence of $31.2 \%$ was found in the group of shelter dogs, while hunting and pet dogs showed lower seroprevalence of $19.5 \%$ and $17.6 \%$, but the difference was statistically insignificant. These results are the first report on the seroprevalence of $\operatorname{IgG}$ antibodies to B. burgdorferi in dogs in the Belgrade area and could be of importance in the assessment of the risk of infection with $B$. burgdorferi in human population.
\end{abstract}

Key words: Borrelia burgdorferi; dogs; IFA; ELISA; Western blot; seroprevalence.

\section{INTRODUCTION}

Lyme borreliosis (LB) is a multisystemic zoonotic disease caused by Borrelia burgdorferi sensu lato (B. burgdorferi s.l.) complex and transmitted by ticks of the genus Ixodes in Europe where small mammals and birds are important reservoirs [1]. Borrelia burgdorferi is a complex classified into more than 15 genospecies, including B. burgdorferi sensu stricto (B. burgdorferi s.s.), B. garinii, B. afzelii, B. spielmanii and B. bavariensis proved as a pathogenic, and B. valaisiana, B. Lusitaniae, and B. bissetii thought to be potentially pathogenic [2]. LB has been detected in humans and in animals, as well. Canine LB was Corresponding author: e-mail: sonjao@vet.bg.ac.rs 
first reported in USA, in 1984 [3]. Clinical manifestations of LB in dogs are nonspecific, they indicate disorders of the musculoskeletal, cardiovascular and nervous systems [4,5], and have been observed in 5-10\% of dogs exposed to B. burgdorferi [6]. The non-specific clinical markers and an absence of significant changes in hematological and biochemical parameters make it difficult to diagnose the disease. Due to the lack of pathognomonic clinical signs in LB, serodiagnostic techniques such as indirect fluorescent antibody assay (IFA), enzyme linked immunosorbent assay (ELISA) and Western blot assay (WB) have become widely used in diagnostics and epidemiological surveys. Direct detection of the pathogen by culture or polymerase chain reaction (PCR) has a minor role in the routine diagnosis of LB. As far as pets are concerned, dogs have been identified as competent reservoirs of B. burgdorferi [7]. Dogs outdoor behavior carries a high risk of contact with infected ticks, and they are considered to be good indicators of LB endemic areas. Therefore, seroprevalence of anti-Borrelia antibodies in dogs could be of importance for the identification of LB endemic areas [8].

In the Belgrade area, human LB was diagnosed in 1987 [9] and according to reports of our relevant institution, Institute of Public Health of Serbia „Dr Milan Jovanović Batut", LB in this area is one of the most common zoonoses in humans [10]. The main vector of $B$. burgdorferi s.l. in Belgrade area is Ixodes ricinus. A high prevalence of borrelia in ticks collected in this area was shown. It ranges from 18.75 to $53.7 \%$, depending on the investigated locality, year and method of detection [11-13]. Five different Borrelia genospecies were detected in I. ricinus ticks from the Belgrade region: B. burgdorferi s.s., B. garinii, B. afzelii, B. valaisiana, and B. lusitaniae [12,13]. In addition, three strains belonging to pathogenic $B$. burgdorferi s.s. and $B$. afzelii genospecies were isolated from small rodents captured in the Belgrade area [14].

Data on LB in the human population in Belgrade were available, which was not the case with data for dogs infected with borrelia in the same region. Therefore, the aim of the study was to investigate the incidence of anti-Borrelia burgdorferi antibodies in dog sera in Belgrade with in-house made IFA, ELISA and WB tests. Also, a comparison of sensitivity and specificity of the in-house tests was conducted.

\section{MATERIALS AND METHODS}

\section{Animals}

Dogs from the Belgrade area (municipalities: Rakovica, Čukarica, Zvezdara, Surčin, Voždovac, Palilula, and Savski Venac) were included in this study. Serum samples of 215 dogs of different breeds, age and of both sexes were taken in the period 20082010. The dogs were of four groups: hunting dogs $(n=41)$, shelter dogs $(n=125)$, pet dogs with clinical signs attributed to infection with B. burgdorferi (shifting limb lameness, swollen joints, fever, and lymphadenopathy) and with described tick exposure $(n=34)$, 
and clinically healthy pet dogs with no tick exposure $(n=15)$. Dogs in Serbia are not routinely vaccinated against $\mathrm{LB}$ so none of the dogs was vaccinated against LB.

Blood was taken from the cephalic vein. Serum was separated after spontaneous coagulation of blood at room temperature. The aliquots were stored at $-20{ }^{\circ} \mathrm{C}$.

\section{Serology}

IFA, ELISA, and WB in-house tests made in our laboratories were used for detection of canine serum $\operatorname{IgG}$ antibodies against B. burgdorferi.

\section{Antigen}

Highly passaged B. burgdorferi strain IRS (ATCC35211) was used. Antigen was prepared from 5-7 day old cultures grown in Barbour-Stoenner-Kelly (BSK) - II medium (Sigma) at $33^{\circ} \mathrm{C}$. Isolates were stored at $-70{ }^{\circ} \mathrm{C}$ in glycerol peptone.

\section{Control sera}

Positive control sera were of subcutaneously immunized dogs $(n=3)$, negative for anti-B. burgdorferi antibodies in WB. They were immunized with $0.5 \mathrm{ml}$ of the whole cell sonicated cultures mixed with $0.5 \mathrm{ml}$ of complete Freund's adjuvant. The antigen was administered three times at intervals of 7 days. Sera collected at day 21 after the first immunization were used as a positive control.

Sera from dogs with no tick bite history and negative for B. burgdorferi infection (WB) were used as negative controls.

\section{IFA}

Cultured borreliae were precipitated by $30 \mathrm{~min}$ centrifugation at $10,000 \mathrm{x} \mathrm{g}$, and washed 3 times in PBS (phosphate buffered saline; $10 \mathrm{mM}$ sodium-phosphate, $0.8 \%$ $\mathrm{NaCl}, \mathrm{pH} 7.2-7.4)$ with $5 \mathrm{mM} \mathrm{MgCl}_{2}$. Serial dilutions of the antigen (1:5 - 1:40 in PBS) were applied on 8 well multispot glass microscopic slides (Sigma). The slides were air dried and fixed in cold acetone. The positive control serum (diluted 1:100 in PBS) was incubated with every dilution of the antigen. As secondary antibody polyclonal rabbit anti $\operatorname{dog}$ IgG antibodies conjugated with FITC (INEP-Zemun, Serbia) (diluted 1:16) were used. The antigen dilution giving 100 bright fluorescent borreliae per field (LEITZ-Orthoplan fluorescence microscope, 400-fold magnification) was declared as optimal. The slides with optimally diluted antigen were prepared and stored at $-70^{\circ} \mathrm{C}$ until use.

For testing purposes, 1:100 diluted tested sera, and positive and negative control sera were placed on the antigen-coated multi spot glass slides and incubated for $30 \mathrm{~min}$ at $37^{\circ} \mathrm{C}$, in a wet chamber. After being washed in PBS and distilled water, and dried, the secondary antibody was added. After $30 \mathrm{~min}$, slides were washed, dried, mounted in 
glycerol/PBS and examined under the fluorescence microscope. A positive reaction was one in which bright green fluorescence was observed.

\section{ELISA}

When preparing the antigen for ELISA the cultured borreliae were pelleted by centrifugation, washed twice with PBS with $5 \mathrm{mM} \mathrm{MgCl}_{2}$, and twice with PBS without $\mathrm{Mg}^{2+}$. The final pellet was resuspended in a 1:1 solution of PBS and $1 \mathrm{M} \mathrm{NaCl}$, and sonicated on ice with a cell sonicator (MSE 150 watt, MSE Scientific Instruments, Sissex, England) [15,16]. The extract was centrifuged, and the protein concentration in the supernatant was determined by the BCA test (Micro BCA Protein Assay Kit, Pierce Technology, USA). Aliquots of the supernatants were kept at $-20^{\circ} \mathrm{C}$.

For the assay, the antigen $(1 \mu \mathrm{g} / \mathrm{ml}$ in $50 \mathrm{mM}$ carbonate buffer, $\mathrm{pH}$ 9.6) was added in 96 flat well polystyrene microtiter plates (Nunc, France). Plates were coated overnight at $4^{\circ} \mathrm{C}$ and then washed three times in PBS with $0.05 \%$ Tween 20 (PBS/Tween). Nonspecific binding was blocked with 5\% non-fat milk (NFM, Carl Roth, GmbH, Karisruhe) diluted in the same buffer. After $1 \mathrm{~h}$ incubation at room temperature and washing, a highly diluted (1:400 in PBS/Tween) [17] positive and negative control sera and test sera were added. After $2 \mathrm{~h}$ the plates were washed and incubated for $1 \mathrm{~h}$ with polyclonal goat anti-dog IgG peroxidase-conjugate (Sigma) secondary antibody (diluted 1:10,000 in PBS/Tween). The peroxidase reaction was visualized with 0.42 mM TMB (3,3',5,5'- tetramethylbenzidine) (Sigma). The reaction was stopped after 20 min with $2 \mathrm{M} \mathrm{H}_{2} \mathrm{SO}_{4}$. The optical density was read at $450 \mathrm{~nm}\left(\mathrm{OD}_{450}\right)$ in a multiplate reader (Multiscan Plus, Labsystem, Finland).

Based on the $\mathrm{OD}_{450}$ values of 40 sera of apparently healthy dogs, negative for anti- $B$. burgdorferi $\mathrm{IgG}$ in WB, a cut off value of 0.440 was obtained. The value was the mean value of $\mathrm{OD}_{450}$ increased by the value of three standard deviations. The coefficient of variation of up to $11 \%$ was obtained by testing 10 negative sera in three independent ELISA tests. The samples with $\mathrm{OD}_{450}$ values within a range of cut off $\pm 11 \%$ were tested again.

\section{WB}

To obtain the antigen for WB cultured borreliae were pelleted by centrifugation, resupended in $10 \mathrm{mM}$ Tris/ $\mathrm{HCl}, 150 \mathrm{mM} \mathrm{NaCl}$ buffer, $\mathrm{pH} 8.0$ containing $1 \mathrm{mM} \mathrm{CaCl}_{2}$ and $1 \mathrm{mM} \mathrm{MgCl}$, and washed two times by centrifugation. The pellet was resuspended in the Tris $/ \mathrm{NaCl}$ buffer without $\mathrm{Ca}^{2+}$ and $\mathrm{Mg}^{2+}$, centrifuged and resuspended in $20 \mathrm{mM}$ Tris/ $\mathrm{HCl}, 300 \mathrm{mM} \mathrm{NaCl}$ buffer $\mathrm{pH}$ 8.0, containing $2 \mathrm{mM}$ EDTA. The protein concentration was measured by the BCA test. Aliquots of the antigen were stored at $-70^{\circ} \mathrm{C}$.

Before commencing the SDS-PAGE, antigen was mixed (1:1) with the reducing sample buffer (125 mM Tris, 4\% SDS, 20\% glycerol, 0.2 M DTT, $0.02 \%$ bromophenol blue, $\mathrm{pH}$ 6.8) and boiled for 5 min. SDS-PAGE in 12.5\%, $1.5 \mathrm{~mm}$ thick gels was carried 
out in SE 260 Mighty Small II Vertical Slab Electrophoresis Unit (GE HealthCare LifeScience, USA). Protein molecular weight standard (Bench Mark, Invitrogen, USA) was included.

The separated proteins were electrotransferred onto nitrocellulose (Hybond ECL, GE HealthCare LifeScience USA) by Multiphor II system (LKB, Uppsala, Sweden) in 25 $\mathrm{mM}$ Tris, $192 \mathrm{mM}$ glycine, 20\% methanol, 0.1\% SDS transfer buffer. Nonspecific binding was blocked with $2.5 \%$ nonfat dried milk in $50 \mathrm{mM}$ Tris/ $\mathrm{HCl}, 100 \mathrm{mM} \mathrm{NaCl}$, pH 7.5 buffer with $0.05 \%$ Tween 20 (TBS/Tween) for $1 \mathrm{~h}$, at room temperature. The membrane was cut into 3 -mm strips and incubated with test and control canine sera (diluted 1:100 in TBS/Tween), for 2h, washed with TBS/Tween and incubated for $1 \mathrm{~h}$ with horseradish peroxidase-conjugated goat anti-dog IgG antibodies (Sigma) diluted 1:2,000 in TBS/Tween. After being washed in TBS/Tween and TBS without Tween, the antibodies reactivity was visualized with $1 \mathrm{mM}$ 4-chloro-1-naphthol (Sigma)-0.03\% $\mathrm{H}_{2} \mathrm{O}_{2}$. The molecular weight of labeled protein was determined using the ImageMaster, TotalLab v1.1 software (GE HealthCare LifeScience, USA). The interpretation of the WB results was done based on the criteria of Hauser et al. (18) where the reactivity with at least one of six protein bands (p83/100, p58, p56, OspC, p21 and p17) in WB with $B$. burgdorferi s.s. indicated a positive reaction.

\section{Statistical analysis}

Specificity and sensitivity of IFA and ELISA was determined using WB as the reference test.

The specificity ( $\mathrm{Sp}$ ) was estimated as the relative frequency of negative results in noninfected dogs and it was calculated using the following formula:

$$
S p=\frac{\text { true negative }}{(\text { true negative }+ \text { false positive })}
$$

The sensitivity (Se) was estimated as the relative frequency of positive results in infected dogs and it was calculated using the following formula:

$$
S e=\frac{\text { true positive }}{(\text { true positive }+ \text { false negative })}
$$

The chi-square test was used to analyze the difference between seroprevalence in groups of dogs. A difference with $\mathrm{p}$-values of $<0.05$ was considered significant. Statistical analysis was carried out by Microsoft Excel.

\section{RESULTS}

The presence of anti-Borrelia IgG antibodies in sera of 215 dogs was analyzed by IFA, ELISA and WB (Table 1). With WB, anti-Borrelia IgG antibodies were found in 53 
$(24.7 \%)$ of 215 sera. With ELISA, 54 (25.1\%) and with IFA 48 (22.3\%) anti-Borrelia IgG positive canine sera were found.

Table 1. Dogs in the Belgrade area having serum anti-Borrelia IgG antibodies

\begin{tabular}{lccccccc}
\hline \multirow{2}{*}{ Group } & \multicolumn{3}{c}{ IFA positive } & \multicolumn{2}{c}{ ELISA positive } & \multicolumn{2}{c}{ WB positive } \\
\cline { 2 - 8 } & No & No & $\mathbf{( \% )}$ & No & $\mathbf{( \% )}$ & No & $\mathbf{( \% )}$ \\
\hline Hunting dogs & 41 & 10 & 24.4 & 9 & 22.0 & 8 & 19.5 \\
Shelter dogs & 125 & 29 & 23.2 & 38 & 30.4 & 39 & 31.2 \\
Pat dogs, suspected* & 34 & 9 & 26.5 & 7 & 20.6 & 6 & 17.6 \\
Pet dogs, healthy & 15 & 0 & 0 & 0 & 0 & 0 & 0 \\
Total & 215 & 48 & 22.3 & 54 & 25.1 & 53 & 24.7 \\
\hline
\end{tabular}

*Household dogs, suspected of having LB

With WB used as the reference test, we determined the performance of IFA and ELISA and identified true and false positive or negative canine sera (Table 2). The sensitivity of IFA was $67.9 \%$ and the specificity was $92.6 \%$. The sensitivity of ELISA was $84.9 \%$ which was higher than the sensitivity of IFA. The specificity of ELISA was $94.4 \%$. Out of 215 analyzed canine sera, 93.5\% (201/215) had the same reactivity (either positive or negative) in both tests.

Table 2. Comparison of anti-B. burgdorferi IgG IFA and ELISA with WB

\begin{tabular}{|c|c|c|c|c|}
\hline \multirow{2}{*}{\multicolumn{2}{|c|}{ Assay and results* }} & \multicolumn{2}{|c|}{ WB } & \multirow{3}{*}{$\begin{array}{r}\text { Tota } \\
48\end{array}$} \\
\hline & & \multirow{2}{*}{$\begin{array}{c}\text { Positive } \\
36\end{array}$} & \multirow{2}{*}{$\begin{array}{c}\text { Negative } \\
12\end{array}$} & \\
\hline \multirow{2}{*}{ IFA } & Positive & & & \\
\hline & Negative & 17 & 150 & 167 \\
\hline \multicolumn{2}{|c|}{ Total } & 53 & 162 & 215 \\
\hline \multirow{2}{*}{\multicolumn{2}{|c|}{ Assay and results* }} & \multicolumn{2}{|c|}{ WB } & \multirow{2}{*}{ Tota } \\
\hline & & Positive & Negative & \\
\hline \multirow{2}{*}{ ELISA } & Positive & 45 & 9 & 54 \\
\hline & Negative & 8 & 153 & 161 \\
\hline \multicolumn{2}{|c|}{ Total } & 53 & 162 & 215 \\
\hline
\end{tabular}

*Number of positive or negative samples

The results of the chi-square test showed that statistically significant differences in seropositivity were found only when the control group of clinically healthy pet dogs with no tick exposure was compared to the other groups. There were no statistically significant differences in prevalence of anti-Borrelia IgG antibodies between groups when the control group was omitted. 


\section{DISCUSSION}

The results of this study showed that anti-B. burgdorferi $\operatorname{IgG}$ antibodies persist in the population of dogs in the Belgrade area. High seroprevalence of $25 \%$ in naturally exposed dogs was confirmed by different tests (IFA, ELISA and WB) widely used for serology diagnostics of LB. The reported tick infection rate in Belgrade is high [11-13], and reported high seroprevalence of anti-B. burgdorferi antibodies in dogs was somewhat expected.

In this study we devised and standardized immunodiagnostic assays based on the methodology applied for diagnosis of LB in humans [16]. It is known that the selection of $B$. burgdorferi s.l. strains for immunodiagnostic tests depends on their frequency in the investigated area. In the Belgrade region different genospecies of B. burgdorferi s.l have been detected, data regarding ticks infection rate with these genospecies are not consistent and protein profiles of every local strain have not been described. Therefore, a reference strain, the European isolate of B. burgdorferi s.s., IRS, was used as the antigen. It is chosen because European researches showed that tests based on the USA originating B31 strain exhibited low diagnostic sensitivity to detect LB in humans and dogs in Europe $[19,20]$.

In order to determine the specificity and sensitivity of in-bouse IFA and ELISA tests created for the detection of anti-B. burgdorferi antibodies it is required to either compare them with commercially available tests or to use highly specific and sensitive WB as a "gold standard" $[21,22]$. In this study, WB was used as the reference standard test. Despite the fact that sensitivity of any WB is not $100 \%$, it is widely used in the evaluation of the results of IFA and ELISA [21,22], and its application precludes a possibility that false negative sera would remain undetected. Also, analyzing the reactivity of serum antibodies of dogs suspected of having LB and asymptomatic dogs from endemic areas with specific proteins of B. burgdorferi in WB is of importance in both clinical practice (were serum antibodies reactivity to specific proteins of B. burgdorferi s.l. could help in determining if observed clinical symptoms are associated with LB), and in epizootic studies (where it could be determined if positive serologic findings obtained by ELISA and IFA are the result of natural infection, vaccination, or presence of cross-reactive antibodies) [17].

Due to the fact that beside B. burgdorferi s.s., abundant presence of B. afzelii was confirmed in the Belgrade area [12-14] we additionally performed WB with a $B$. afzelii strain (human skin isolate obtained from University of Ljubljana, Slovenia) where positive reaction presented a reactivity with at least two of nine protein bands (p83/100, p58, p43, p39, p30, OspC, p21, p18/p17 and p14) (criteria of Hauser et al.) [18]. A statistical analysis revealed that there was a high compliance of the results of these two WB assays (article in press). Based on these results we considered that it was possible to use WB prepared with B. burgdorferi s.s. for estimating the prevalence of antibodies against $B$. burgdorferi s.l. in dogs in our region. 
Analyzing the epizootic situation in neighboring countries and throughout Europe, it could be noticed that the canine seroprevalence rates varied depending on the investigated regions, applied immunodiagnostic tests, interpretations of results in terms of positive reactivity, and Borrelia strains used in the tests [21,23]. Data on the seroprevalence of dogs in Europe is mainly based on the results of IFA and ELISA, while WB was rarely used for estimating the epizootic situation [24,25].

With anti-B. burgdorferi IFA we detected $22.3 \%$ positive canine sera. Good specificity but low sensitivity of IFA observed in this study was in accordance with the results of Lindenmayer et al. [22]. Similar sensitivity and specificity of IFA was shown when reactivity of human serum against $B$. burgdorferi was estimated [16]. Regardless of the low sensitivity, IFA is frequently used in epizootic researches [26-28]. Yet, our results point out that with IFA test more than $30 \%$ of infected dogs remained undetected. This indicated a necessity of application of ELISA as a more sensitive test. With in-house ELISA we found the canine seroprevalence rate in the Belgrade area to be $25.1 \%$. In Vojvodina Province (northern part of Serbia), with a commercial ELISA, similar canine seroprevalence of $25.5 \%$ was detected [24]. The congruence of canine seroprevalence between Belgrade area and Vojvodina is also present if we compare results of WB. We detected by WB $24.7 \%$ positive dog sera. Almost identical seroprevalence results $(26.1 \%)$ were obtained for dogs in Vojvodina, when a commercial WB was applied [24]. It is interesting that Potkonjak et al. [29] reported canine seroprevalence rate of $8.1 \%$ in Vojvodina, obtained by using indirect ELISA, and rapid immunochromatographic and immunoblot tests for the confirmation of reactive blood serums.

Numerous studies reported canine seroprevalence against Borreliae throughout Europe. Using ELISA, Turk et al. [30] examined random healthy dogs in the Zagreb area [Croatia] and found 5\% of positive sera. Similar seroprevalence of $6.2 \%$ was reported for healthy dogs from Bulgaria [28]. In Romania, seropositivity detected by ELISA and IFA was in the range of $0-46 \%$, depending on the region, with an overall prevalence of anti-Borrelia antibodies of $6.52 \%$ [31]. In different regions of Czech Republic canine seroprevalence detected by ELISA was between 0 and 28\% with an average of 6.5\% [20], while Kybicová et al., [32] detected IgG antibodies to B. burgdorferi in $10.3 \%$ of dogs. Out of 448 randomly selected dogs in Munich, Germany, $4.9 \%$ showed the presence of antibodies agains B. burgdorferi after screening with the SNAP 4Dx assay (IDEXX, Westbrook, Maine, USA) [33]. In the Netherlands, Goossens et al. [34] found a relatively high (17\%), seroprevalence of B. burgdorferi among dogs of using whole-cell ELISA. On the other hand, lower seroprevalence rates in apparently healthy dogs were detected in Portugal $(0.2 \%)$, Spain $(0.4 \%)$, and Latvia $(2.5 \%)$ [35-37]. Low seroprevalence of B. burgdorferi found among dogs in these countries could be explained by their position at the northern and southern borders of $I$. ricinus areal, where activity of ticks is spatially and temporally restricted, and consecutively exposure of dogs to Borreliae vectors is lower. In Voronezh Reserve, Russia, unexpectedly low seroprevalence of B. burgdorferi in dogs of $2.4 \%$, in the area which has never been treated with acaricides, was reported [38]. 
Results of a survey carried out in the Netherlands showed that there was no difference in seroprevalence to B. burgdorferi between hunting (19.5\%) and pet dogs $(17.6 \%)$ [40]. However, Stefancíková et al. [23] showed that in Slovakia (area of Kosice) the seroprevalence rate in hunting dogs (40\%) was significantly higher than the one found in the service dog population (11.8\%). Although seroprevalence rate of B. burgdorferi in shelter dogs was higher in comparison to hunting and suspected pet dogs in our study, the detected differences were not statistically significant.

A close connection between the distribution of ticks of the genus Ixodes and prevalence of LB in both humans and dogs was shown, and it is believed that data on seroprevalence of anti-Borrelia antibodies in dogs can be useful in identifying potentially dangerous areas for both dog and human populations [8]. Results of this study are the first report concerning seroprevalence of anti-Borrelia antibodies in dogs in the Belgrade area. The relatively high seroprevalence found in this study supports the previous thesis based on high borrelia prevalence in host-seeking ticks in this area, Belgrade being an endemic region of LB, and again confirmed that dogs may be used as sentinels for human exposure to LB. In addition to previous studies [39], this study also contributes to the elucidation of the still incompletely known epizootic situation in the Belgrade area.

\section{Acknowledgement}

This work was supported by the Ministry of Education, Science and Technological Development of the Republic of Serbia, Grants OI175062, OI173006 and TP 31088.

We thank prof dr Tadej Malovrh, Faculty of Veterinary Medicine, University of Ljubljana, Slovenia, for giving us the isolate of B. afzelii.

\section{REFERENCES}

1. Kurtenbach K, Peacey M, Rijpkema SG, Hoodless AN, Nuttall PA, Randolph SE: Differential transmission of the genospecies of Borrelia burgdorferi sensu lato by game birds and small rodents in England. Appl Environ Microbiol 1998, 64:1169-1174.

2. Margos G, Vollmer SA, Cornet M, Garnier M, Fingerle V, Wilske B, Bormane A, Vitorino L, Collares-Pereira M, Drancourt M, Kurtenbach K: A new Borrelia species defined by multilocus sequence analysis of housekeeping genes. Appl Environ Microbiol 2009, 75:5410-5416.

3. Lissman BA, Bosler EM, Camay H: Spirochete associated arthritis (Lyme disease) in a dog. JAVMA 1984, 185: 219-220.

4. Levy S, Dury PH: Complete heart block in a dog seropositive for Borrelia burgdorferi. J Vet Intern Med 1988, 2:138-144.

5. AzumaY, Kawamura K, Isogai H, Isogai E: Neurologic abnormalities in two dogs suspected Lyme disease. Microbiol Immunol 1993, 37:325-329. 
6. Levy SA, Magnarelli LA: Relationship between development of antibodies to Borrelia burgdorferi in dogs and the subsequent development of limb/joint borreliosis. JAVMA 1992, 200:344-347.

7. Mather TN, Fish D, Coughlin RT: Competence of dogs as reservoir for Lyme disease spirochetes (Borrelia burgdorferi). JAVMA 1994, 205:186-188.

8. Eng TR, Wilson ML, Spielman A, Lastavica CC: Greater risk of Borrelia burgdorferi infection in dogs than in people. J Infect Dis 1988, 158:1410-1411.

9. Dmitrović R: Lyme disease in Yugoslavia [In Serbian: Lajmska bolest u Jugoslaviji] Velarta; Belgrade, Serbia, 1996.

10. Institute of Public Health of Serbia „Dr Milan Jovanović Batut” 2012: Health scientific yearbook Republic of Serbia [http://wwwbatutorgrs/download/publikacije/pub2012pdf].

11. Milutinović M, Radulović Ž, Jovičić V, Oreščanin Z: Population dynamics and Borrelia burgdorferi infection rate of Ixodes ricinus ticks in the Belgrade area. Acta Veterinaria (Beograd] 2004, 54:219-225.

12. Milutinović M, Masuzawa T, Tomanović S, Radulović Ž, Fukui T, Okamoto Y: Borrelia burgdorferi sensu lato, Anaplasma phagocytophilum, Francisella tularensis and their co-infections in host-seeking Ixodes ricinus ticks collected in Serbia. Exp Appl Acarol 2008, 45:171-183.

13. Cekanac R, Pavlovic N, Gledovic Z, Grgurevic A, Stajkovic N, Lepsanovic Z, Ristanovic E: Prevalence of Borrelia burgdorferi in Ixodes ricinus ticks in Belgrade area. Vector Borne Zoonotic Dis 2010, 10:447-452.

14. Ristanovic ES, Kitamura K, Masuzawa T, Milutinovic MJ, Cekanac RM, Stajkovic NT, Živanovic DM: Molecular characterization of Borrelia burgdorferi sensu lato strains isolated in the area of Belgrade, Serbia. Brazilian Journal of Microbiology 2007, 38:14-16.

15. Craft JE, Grodzicki RL, Steere AC: Antibody response in Lime disease-evaluation of diagnostic tests. J Infect Dis 1984, 193:265-275.

16. Jovičić VLj, Grego EM, Lako BL, Ristović BM, Lepšanović ZA, Stajković NT: Improved serodiagnosis of early Lyme borreliosis: Immunoblot with local Borrelia afzelii strain. APMIS 2003, 311: 1053-1059.

17. Guerra MA, Walker ED, Kitron U: Quantitative Approach for the Serodiagnosis of Canine Lyme Disease by Immunoblot Procedure. J Clin Microbiol 2000, 38: 2628-2632.

18. Hauser U, Lehnert G, Lobentanzer R, Wilske B: Interpretation criteria for standardized Western blots for three European species of Borrelia burgdorferi sensu lato. J Clin Microbiol 1997, 35:1433-1444.

19. Štefančikova A, Tresova G, Petko B, Skardova I, Sesztakova E: ELISA comparison of three whole cell antigens of Borrelia burgdorferi sensu lato in serological study of dogs from area of Kosice, Eastern Slovakia. Ann Agric Environ Med 1998, 5:25-30.

20. Pejchalova, K, Žarkovska A, Fučik K, Schanilec P: Serological Confirmation of Borrelia burgdorferi Infection in Dogs in the Czech Republic. Vet Res Commun 2006, 30:231-238.

21. Greene RT, Hirsch DA, Rottman PL, Gerig TM: Interlaboratory Comparasion of Titers of Antibody to Borrelia burgdorferi and Evaluation of a Commercial Assay Using Canine Sera J Clin Microb 1991, 29:16-20.

22. Lindenmayer J, Weber M, Bryant J, Marquez E, Onderdonk A: Comparison of indirect immunofluorescent-antibody assay, enzyme-linked immunosorbent assay, and Western immunoblot for the diagnosis of Lyme disease in dogs. J Clin Microbiol 1990, 28:92-96.

23. Hovius JWR, Hovius KE, Oei A, Houwers DJ, van Dam AP: Antibodies against specific proteins of and immobilizing activity against three strains of Borrelia burgdorferi sensu lato 
can be found in symptomatic but not in infected asymptomatic dogs. J Clin Microbiol 2000, 38:2611-2621.

24. Savić S, Vidić B, Lazić S, Lako B, Potkonjak A, Lepsanović Z: Borrelia burgdorferi in ticks and dogs in the province of Vojvodina, Serbia. Parasite 2010, 17:357-361.

25. Leschnik M, Feiler A, Duscher GG, Joachim A: Effect of owner-controlled acaricidal treatment on tick infestation and immune response to tick-borne pathogens in naturally infested dogs from Eastern Austria. Parasit Vectors 2013, 6:62.

26. Merino FJ, Serrano JL, Saz JV, Nebreda T, Gegundez M, Beltran M: Epidemiological characteristics of dogs with Lyme borreliosis in the province of Soria (Spain]. Eur J Epidemiol 2000, 16:97-100.

27. Žarkov I, Martinov M: The Lyme disease results of a serological study in sheep, cows and dogs in Bulgaria. Revia Med Vet 2003, 154: 363-366.

28. Martinov S, Halacheva M, Nedelchev N, Aleksandrov E: Contemporary state of the tickborne transmissible infections in domestic animals in Bulgaria. Vet Med X 2006, 3-4:7-18.

29. Potkonjak A, Savić S, Vračar V, Rnjak D, Tikvicki M, Obrenović S, Lako B: Prevalence of G class antibodies to antigens of lyme disease causes in dogs in Vojvodina, Serbia [n Serbian: Prevalencija antitela klase $G$ na antigene uzročnika lajmske bolesti kod pasa u Vojvodini, Srbija] Vet glasnik 2013, 67:55-66.

30. Turk N, Marinculić A, Modrić Z: Serologic studies of canine Lyme borreliosis in the Zagreb area (Croatia]. Veterinarski arhiv 2000, 70:39-45.

31. Kiss T, Cadar D, Krupaci AF, Bordeanu A, Brudaşcă GF, Mihalca AD, Mircean V, Gliga L, Dumitrache MO, Spînu M: Serological reactivity to Borrelia burgdorferi sensu lato in dogs and horses from distinct areas in Romania. Vector Borne Zoonotic Dis 2011, 11:1259-1262.

32. Kybicová K, Schánilec P, Hulínská D, Uherková L, Kurzová Z, Spejchalová: Detection of Anaplasma phagocytophilum and Borrelia burgdorferi sensu lato in dogs in the Czech Republic. Vector Borne Zoonotic Dis 2009, 9:655-661.

33. Barth C, Straubinger RK, Sauter-Louis C, Hartmann K: Prevalence of antibodies against Borrelia burgdorferi sensu lato and Anaplasma phagocytophilum and their clinical relevance in dogs in Munich, Germany. Berl Munch Tierarztl Wochenschr 2012, 125:337-444.

34. Goossens HA, van den Bogaard AE, Nohlmans MK: Dogs as sentinels for human lyme borreliosis in The Netherlands. J Clin Microbiol 2001, 39:844-848.

35. Cardoso L, Mendão C, Madeira de Carvalho L: Prevalence of Dirofilaria immitis, Ehrlichia canis, Borrelia burgdorferi sensu lato, Anaplasma spp and Leishmania infantum in apparently healthy and CVBD-suspect dogs in Portugal--a national serological study. Parasit Vectors 2012, 5:62.

36. Miró G, Montoya A, Roura X, Gálvez R, Sainz A: Seropositivity rates for agents of canine vector-borne diseases in Spain: a multicentre study. Parasit Vectors 2013, 6:117.

37. Berzina I, Matise I: Seroprevalence against Borrelia burgdorferi sensu lato and occurence of antibody co-expression with Anaplasma phagocytophilum in dogs in Latvia. Ir Vet J 2013, 66:9.

38. Volgina NS, Romashov BV, Romashova NB, Shtannikov AV: Prevalence of borreliosis, anaplasmosis, ehrlichiosis and Dirofilaria immitis in dogs and vectors in Voronezh Reserve (Russia]. Comp Immunol Microbiol Infect Dis 2013, 36:567-574.

39. Obrenović S, Radojičić S, Stević N, Bogunović D, Vakanjac S, Valčić M: Seroprevalence of cat leptospirosis in Belgrade (Serbia). Acta Veterinaria 2014, 64: 510-518. 


\title{
SEROPREVALENCIJA IgG ANATITELA NA BORRELIA BURGDORFERI KOD PASA NA PODRUČJU BEOGRADA
}

\author{
OBRENOVIĆ Sonja, RISTANOVIĆ Elizabeta, ČEKANAC Radovan, \\ RADULOVIĆ Željko, ILIĆ Vesna
}

Cilj ove studije bio je da se ispita prisustvo IgG antitela na Borrelia burgdorferi (B. burgdorferi] u populaciji pasa sa područja Beograda. Serumi 215 pasa su ispitivani u laboratoriji pripremljenim i standardizovanim testom indirektne imunofluorescencije (IFA], imunoenzimskim testom (ELISA] i Western blotom (WB]. Ispitani su serumi 34 kućna psa sa simptomima koji mogu ukazivati na Lajm boreliozu, 41 lovačkog psa, 125 pasa lutalica i 15 kućnih klinički zdravih pasa. Na osnovu rezultata WB, koji je korišćen kao standardni test, procenjena je specifičnost i osetljivost IFA i ELISA testova. Utvrđena je veća osetljivost ELISA testa u odnosu na IFA (84,8\% u odnosu na 67,9\%], dok je specifičnost ova dva testa bila približno jednaka (94,4\% u odnosu na 92,6\%]. Imunoblotom tj. Western blotom je detektovana seroprevalencija na B. burgdorferi kod pasa od 24,7\%. Najveća seroprevalencija na B. burgdorferi od 31,2\% je detektovana u grupi pasa lutalica. Niža, ali ne i statistički značajno različita, seroprevalencija od 19,5\% i $17,6 \%$ detektovana je u grupi lovačkih pasa i kućnih pasa sa sumnjom na Lajm boreliozu. Prikazani rezultati su prvi podaci o prevalenciji antitela na B. burgdorferi kod pasa na području Beograda i istovremeno mogu da budu od značaja za procenu rizika od infekcije B. burgdorferi kod ljudi. 